\title{
Fate and Effects of Cadmium in Marine Plankton Communities in Experimental Enclosures*
}

\author{
Jan Kuiper \\ Laboratory for Applied Marine Research, Division of Technology for Society TNO, P. O. Box 57, 1780 AB Den Helder, \\ The Netherlands
}

\begin{abstract}
Fate and effects of cadmium on the development of North Sea coastal plankton communities, enclosed in plastic bags containing $1.5 \mathrm{~m}^{3}$ natural water, were studied in 2 experiments. Both experiments were carried out in summer-autumn and lasted 11 and 7 weeks respectively. Cadmium chloride was added to different bags in single doses of 1,5 and $50 \mu \mathrm{Cd} \mathrm{l}^{-1}$; in the first experiment additional doses of 100 and $250 \mu \mathrm{g} \mathrm{Cd} \mathrm{^{-1 }}$ were added in the middle of the experiment to 2 of 6 bags. At the end of the experiments $4-9 \%$ of the added cadmium was recovered in the sediment, the remainder was still in the water phase. Addition of 5 or $50 \mu \mathrm{g} \mathrm{Cd} \mathrm{l}^{-1}$ resulted in slightly higher phytoplankton concentrations in one experiment. The mortality of copepods was increased by addition of 250 or $100 \mu \mathrm{g}$

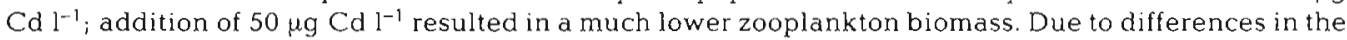
sensitivity of different species, addition of $50 \mu \mathrm{g} \mathrm{Cd} \mathrm{l}^{-1}$ caused a change in species composition of the zooplankton community compared to controls. Growth of Pleurobrachia pileus was inhibited at 5 and $1 \mu \mathrm{Cd} \mathrm{l}^{-1}$, leading to differences in the numbers of copepods between controls and treated bags. At

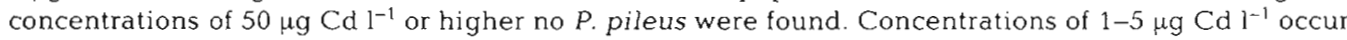
locally in polluted waters. The first experiment lasted more than 3 months and showed that nutrient regeneration rates in the bags are large enough to enable the system to persist without artificial nutrient additions.
\end{abstract}

\section{INTRODUCTION}

In nature large and little-understood variations frequently occur in ecologically important parameters such as population density and species composition. It is therefore difficult to detect long-term effects of environmental stress in the field. Much of our knowledge of the influence of individual pollutants on the marine ecosystem comes from actual dumping practice and from tanker and other disasters.

Although laboratory experiments are indispensable and yield useful information, extrapolation of their results to field conditions is at present difficult, if not impossible. In order to assess the value of experiments in the laboratory, there is a need for experiments with more complex systems that can be regarded as approximating field conditions more closely (Ringelberg, 1973; Menzel and Case, 1977).

To bridge the gap between the laboratory and the aquatic environment, several investigators use large

- This work was carried out under contract No. 227-77-1 ENV N of the E. C. Environmental Research Programme plastic bags suspended in natural water (e. g. Strickland and Terhune, 1961; Menzel and Case, 1977. Davies and Gamble, 1979). This type of research, using Dutch coastal water plankton communities, was started in 1974. When it had been shown that the method of enclosing a plankton community in a plastic bag could be used for toxicological research (Kuiper, 1977a, cf. Takahashi et al. 1975), further investigation was aimed at developing the method and at determining the impact of pollutants in low concentrations on the development of the enclosed system (Kuiper, 1977b, 1981). This paper describes 2 experiments in which cadmium chloride was used as model pollutant. Cadmium was chosen because of its increasing importance as a pollutant in the field (Abdullah et al., 1972; Preston, 1973; CEC, 1974; Ketchum et al., 1975).

Apart from studying fate and effects of cadmium on the development of plankton communities in bags, the first experiment was also used to test the hypothesis that nutrient regeneration rates in the bags are large enough to enable the ecosystem to persist over considerable time without artificial nutrient additions, which are necessary in much larger, stratified enclosed water 
columns (Menzel and Case, 1977; Davies and Gamble, 1979).

\section{MATERIALS AND METHODS}

\section{Experimental Handling}

Construction of the bags and experimental procedures have been described in detail by Kuiper (1977a). The first experiment started on 17 May and ended on 18 August 1976. The intensive sampling programme described below ended on 15 June. The second experiment started on 7 September and ended on 25 October 1976.

In each experiment 6 bags were filled simultaneously with about 1400 l of North Sea water, collected a few miles off shore. The bags were anchored near a raft in the harbour of Den Helder (The Netherlands). Large predators (Ctenophora, fish larvae) were prevented from entering the bags by filtration of the water through a $2 \mathrm{~mm}$ net.

In all experiments single doses of cadmium chloride were added. To this end $100 \mathrm{l}$ of water was pumped out of each bag into a PVC container and rapidly mixed with 1 l of a concentrated solution of cadmium chloride in acidified water $(0.1 \mathrm{ml} 12 \mathrm{M}$ hydrochloric acid). This mixture was at once pumped back into the bag through a PVC sprinkler, which was slowly lowered into the bag to ensure thorough mixing of the solution with the seawater in the bag. In the first experiment cadmium chloride was added on Day 3 (the start of an experiment being Day 0) to 4 bags to give initial concentrations of 1,5 (2 bags) and $50 \mu \mathrm{g} \mathrm{Cd} \mathrm{l}^{-1}$. Two bags were treated identically without addition of cadmium and served as controls. Because on Day 22 no clear effects of the addition of cadmium were expected, an additional dose was given on Day 23 to 2 bags to give concentrations of 100 and $250 \mu \mathrm{g} \mathrm{Cd} \mathrm{l^{-1 }}$ respectively. In the second experiment cadmium chloride was added on Day 10 to give initial concentrations of 1,5 (2 bags)

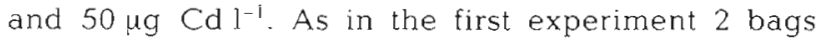
served as controls.

Samples, except those of zooplankton, were taken daily, as a rule at 9 a. $\mathrm{m}$. Zooplankton samples were collected by means of a pipe (length $3 \mathrm{~m}$, diameter $4 \mathrm{~cm}$ ) with a ball valve at the end, sampling nearly the whole water column $(0-2.5 \mathrm{~m})$. Each sample (15.7) consisted of 5 lowerings of the pipe into each bag. The contents of the sampler were filtered through a $55 \mathrm{um}$ net, and the retained material was at once fixed and preserved in a $4 \%$ solution of formaldehyde in filtered seawater.

During the first experiment the (non-metallic) zooplankton sampler was also used to collect the samples for the other analyses (integrated sample $0-2.5 \mathrm{~m}$ depth). During the second experiment samples for phytoplankton, nutrients, etc. were collected with a nonmetallic sampler consisting of 2 chambers that could be opened at any desired depth. To investigate the variation of selected parameters with depth, samples were always taken at depths of 0.5 and $2.0 \mathrm{~m}$.

During the first experiment the ctenophore Pleurobrachia pileus developed in considerable numbers. These numbers were estimated as follows: a Secchi disc (diameter $15 \mathrm{~cm}$ ) was lowered to a depth of $1.5 \mathrm{~m}$ in the bags. During a period of $30 \mathrm{~min}$ the number of $P$. pileus in the water column above the Secchi disc was recorded every minute. The average number recorded, multiplied by 47 ( = total depth of bag/1.5 times area bag/area disc) gives an estimate to the total number of $P$. pileus in the bag. The reproducibility of the measurement itself is good (s. d. of a single measurement was estimated to be $10 \%$ ), but no information about the error of the estimate was obtained. The advantage of this method is that it gives an estimate of the number of $P$. pileus without killing them. The bags are too small to allow an estimate of their number by sampling.

At the end of the experiment the sedimented material was collected from the bottom of the bag by SCUBA divers using a large, non-metallic injection syringe.

\section{Analytical Methods}

The chlorophyll concentration was measured according to Strickland and Parsons (1968). The samples of phytoplankton were preserved with Lugol's iodine (Vollenweider, 1969) and examined with a Zeiss inverted microscope (UtermöhI, 1958). The main species were identified, where possible using nomenclature given by Ingram Hendey (1964) and Drebes (1974).

Concentration and size distribution of suspended particulate matter were measured in unpreserved samples with a Coulter Counter, Model TA Il fitted with a population accessory, using a $100 \mu \mathrm{m}$ or a $280 \mu \mathrm{m}$. tube or both (Sheldon and Parsons, 1967, Gamble et al., 1977)

Primary production was measured during the second experiment employing Steemann Nielsen's (1952) ${ }^{14} \mathrm{C}$ method. Samples of $100 \mathrm{ml}$ were added to $1 \mathrm{ml}$ of $\mathrm{NaH}\left[{ }^{14} \mathrm{C}\right] \mathrm{O}$, solution (ampoules with an activity of $3.6 \mu \mathrm{Ci} \mathrm{ml} \mathrm{ml}^{-1}$ were supplied by the International Agency for ${ }^{14} \mathrm{C}$ determination, Horsholm, Denmark) in $125 \mathrm{ml} \mathrm{light}$ and dark bottles. One light and one dark bottle were suspended at depths of 0.5 and $2.0 \mathrm{~m}$ in the bags. After $6 \mathrm{~h}$ of incubation ( $9 \mathrm{a} . \mathrm{m} .-3 \mathrm{p} . \mathrm{m}$.) the 
bottles were taken to the laboratory in a dark box, and their contents filtered.

Each filter was put in a counting vial containing $10 \mathrm{ml}$ of a scintillation solution (Anderson and Zeutschel, 1970; Pugh, 1973). The vials were counted with a Packard Tricarb liquid scintillation counter The inorganic carbon content of the water was determined by titration according to Strickland and Parsons (1968)

The concentrations of orthophosphate, ammonia, nitrate, nitrite and reactive silicate were measured with a Technicon autoanalyzer according to Strickland and Parsons (1968) and Technicon procedures.

The zooplankton was counted, identified and measured by the procedures described by Fransz (1976); nauplii and copepodites of each species were divided into at least 6 size classes and the adults separated by sex. Subsamples of the 15.7 I sample were examined with a microscope until at least 150 arganisms had been counted. Changes in population densities at the various stages of copepods development - copepods always form the major part of zooplankton biomass in the bags - were used to estimate development and mortality rates of selected species, using multiple regression analysis of abundance of size classes (stages) at the various sampling dates (Fransz, 1976). Production of organic matter by copepods was estimated by multiplying the means between zero and the upper limit of the $95 \%$ confidence interval of development rates by the mean density and the weight increment for each time interval (Fransz, 1976). Dry weights of the copepods were derived from regression of dry weight on cephalothorax length given by Robertson (1968) and Nassogne (1972)

Other parameters measured include water temperature, salinity, Secchi-disc visibility, oxygen concentration, $\mathrm{pH}$ and global radiation (Mollgorczynski radiation meter). Unfjltered water samples for cadmium analysis were preserved with nitric acid (supra pur, samples $\mathrm{pH}=2$ ). Cadmium was extracted from the samples and analyzed by atomic absorption spectrometry following procedures described by Fonds and Estrof (1973). Cadmium concentrations in the sediment were measured by neutron activation analysis according to Tjoe et al. (1973).

\section{Statistics}

Most statistical analyses (Analysis of variance, Student's-t, sign-test, Wilcoxon test) were performed on the CDC 6400 computer of IWIS-TNO, The Hague. Computations for the zooplankton analyses were conducted with the CDC 6600 of the Nuclear Centre at Petten (with the help of Dr. H. G. Fransz of the Netherlands Institute of Sea Research. Texel). In all cases where no confidence level is given $P<0.05$ was tested.

\section{RESULTS}

\section{Phytoplankton During the First Experiment}

The water that was used to fill the bags was relatively clear (Secchi disc visibility $2.6 \mathrm{~m}$ ) and had a salinity of $31 \% \mathrm{~S}$. The temperature during the first 60 days was around $14{ }^{\circ} \mathrm{C}$, thereafter temperatures increased to $20^{\circ} \mathrm{C}$. Fig. 1 shows the cadmium concentrations in the different bags during the experiment.

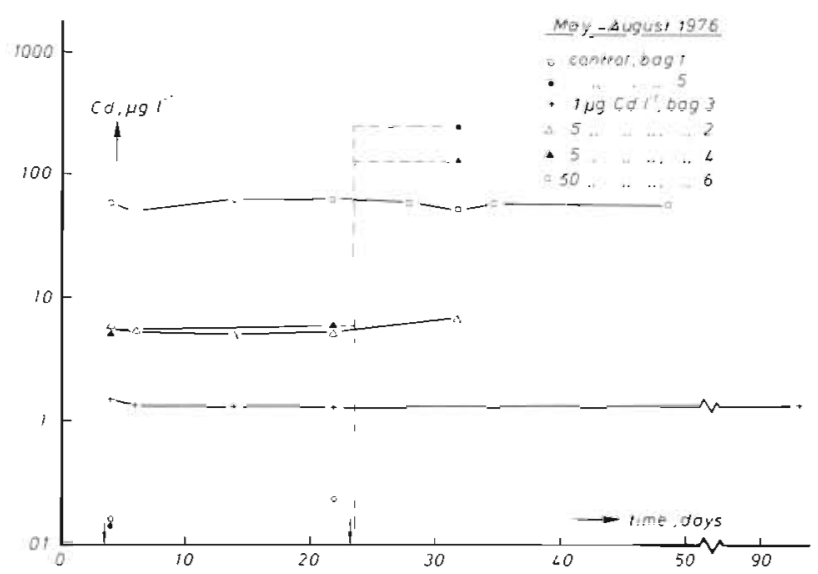

Fig. 1. Cadmium concentrations in water during first experinuent

Most cadmium remained in the water phase. Even on Day $931.4 \mu \mathrm{g} \mathrm{Cd]^{-1 }}$ was measured in Bag 3 (actual initial concentration $1.5 \mu \mathrm{g} \mathrm{Cd}{ }^{\prime}$ ). The development of chlorophyll concentrations is shown in Fig. 2 (depth integrated samples $0-2.5 \mathrm{~m}$ ). The initial concentrations of $1 \mathrm{mg} \mathrm{m}^{3}$ was relatively low. The phytoplankton community consisted of diatoms (Biddulphia regia, $B$. sinensis, Asterionella japonica, Chaetoceros spp.), large flagellates (cf. Rhodomonas sp.) and $\mu$-flagellates. Of these species the large flagellates and $\mu$ flagellates started to reproduce immediately after the bags were filled, producing a chlorophyll maximum on Day 4 or 5. A minimum was reached on Day 7. On Day 14 a second chlorophyll maximum was produced by diatoms, of which Lauderia borealis was the main species. Only low numbers of $\mu$-flagellates and larger flagellates were found on Day 14.

Considering the first 22 days of the experiment it appears that chlorophyll concentrations were higher than in the controls after addition of $50 \mu \mathrm{g} \mathrm{Cd} \mathrm{l}^{-1}$, and on the average slightly higher after addition of $5 \mu \mathrm{g}$ $\mathrm{Cd}^{-1}$ Analysis of variance gave an estimate for the 


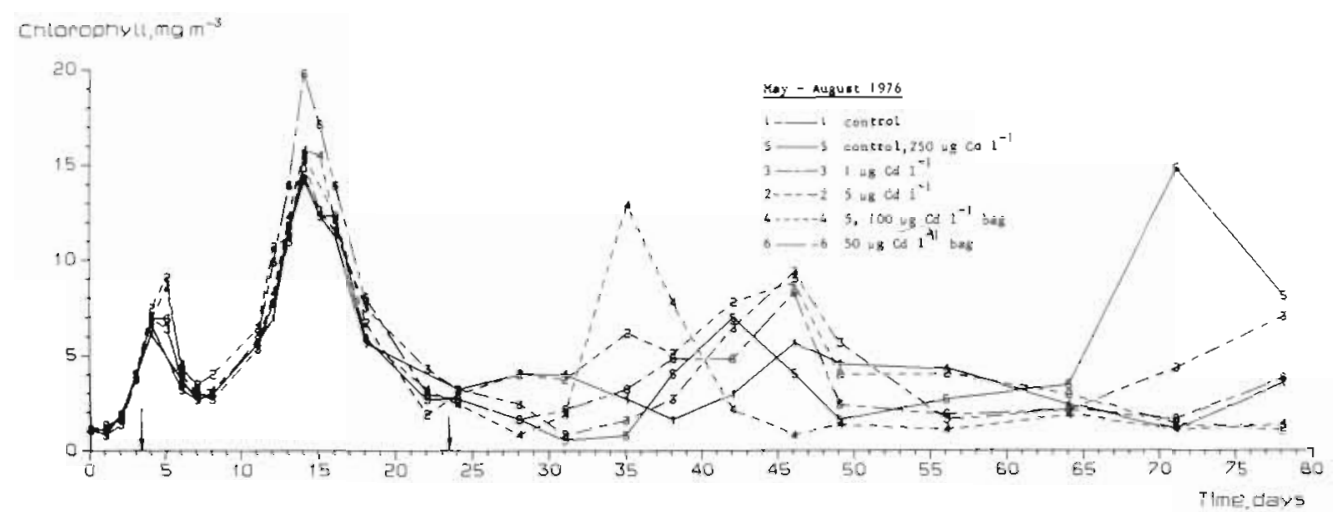

Fig. 2. Chlorophyll concentrations in different bags during first experiment

variation coefficient of the chlorophyll measurement from Day 4-22 (5\%). Using this variation coefficient it could be shown (Student's test) that chlorophyll con-

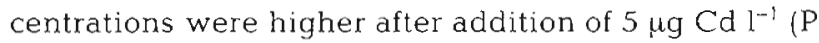
$\leqslant 0.02)$ and $50 \mu \mathrm{g} \mathrm{Cd}^{-1}(\mathrm{P} \leqslant 0.05)$. In a short additional experiment, addition of 5 or $50 \mu \mathrm{g} \mathrm{Cd} \mathrm{l^{-1 }}$ again led to higher chlorophyll concentrations in the bags (Kuiper, 1980). On Day 23 additional doses of 100 and $250 \mu \mathrm{g}$ $\mathrm{Cd} \mathrm{l}^{-1}$ were added to one $5 \mu \mathrm{g} \mathrm{Cdl^{-1 }}$ bag and one control bag respectively. A clear influence of these additions could not be detected.

Mineralization in the bags was apparently large enough to supply the phytoplankton with nutrients necessary for growth. It is also clear that later in the experiment (after Day 25) only a few species of small $\mu$ flagellates were able to survive in the bags. The comparability with the natural system was by this time low. After nearly 3 months the material of which the bags were made began to distintegrate, especially at the water surface. The first and second phytoplankton bloom (1st: flagellates, 2nd: diatoms) depleted the available nutrients until some nutrient reached growth rate limiting values. The nutrient which limited growth of the flagellates is not clear, it was probably not one of those measured. The growth of Lauderia borealis was probably limited by lack of silicate (Van Bennekom et al. 1975; Kuiper, 1977a).

\section{Phytoplankton During the Second Experiment}

The bags were filled on Day $O$. The salinity of the water was $31^{\prime \prime}$. S, Secchi disc visibility $1.5 \mathrm{~m}$. Temperatures were around $15^{\circ} \mathrm{C}$ throughout the experiment. As in the first experiment, the added cadmium remained in the water phase throughout the experiment.

Fig. 3 shows the chlorophyll concentrations in the bags as a function of time. At the start of the experiment the community consisted of diatoms (Chaetoceros

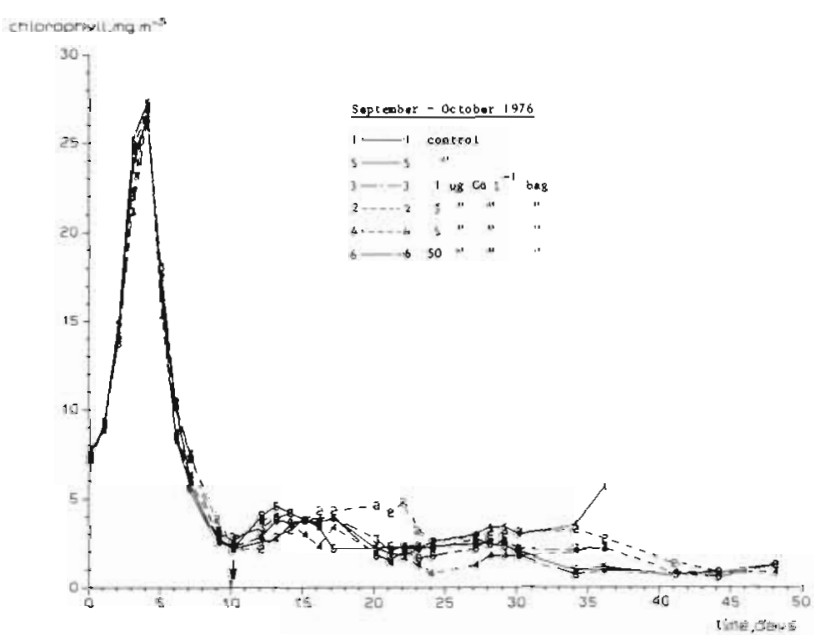

Fig. 3. Chlorophyll concentrations in different bags during second experiment (average of 0.5 and $2.0 \mathrm{~m}$ depth)

spp., Leptocylindrus danicus, Coscinodiscus sp., Asterionella japonica) and flagellates (Prorocentrum spp. an $\mu$-flagellates). Different diatoms started growing after the filling of the bags, Chaetoceros sp. being the dominant species. These produced a chlorophyll maximum on Day 4; a minimum was reached on Day 10 (the day of addition of cadmium). After Day 10 , chlorophyll concentrations stayed relatively low in all bags. A second maximum, caused by growth of dinoflagellates and $\mu$-flagellates (Prorocentrum redfieldi being the dominant species), was reached on different days in the different bags. An influence of the addition of cadmium on the development of chlorophyll concentrations could not be shown. A detailed microscopical analysis of the phytoplankton could not show any significant differences in the species composition between the different bags (test of Wilcoxon).

The carbon assimilation was measured from Day 116. It appeared that most of the differences between the measurements on a single depth could be attributed to differences in biomass. Therefore the result- 
ing values were divided by the chlorophyll concentrations. This relative carbon assimilation at depths of 0.5 and $2.0 \mathrm{~m}$ is presented in Fig. 4. No large differences were found between the bags. Depth, i.e. light regime had a large influence on relative carbon assimilation. Interestingly, after Day 10 , the relative carbon assimi-

relative carbon assimilation
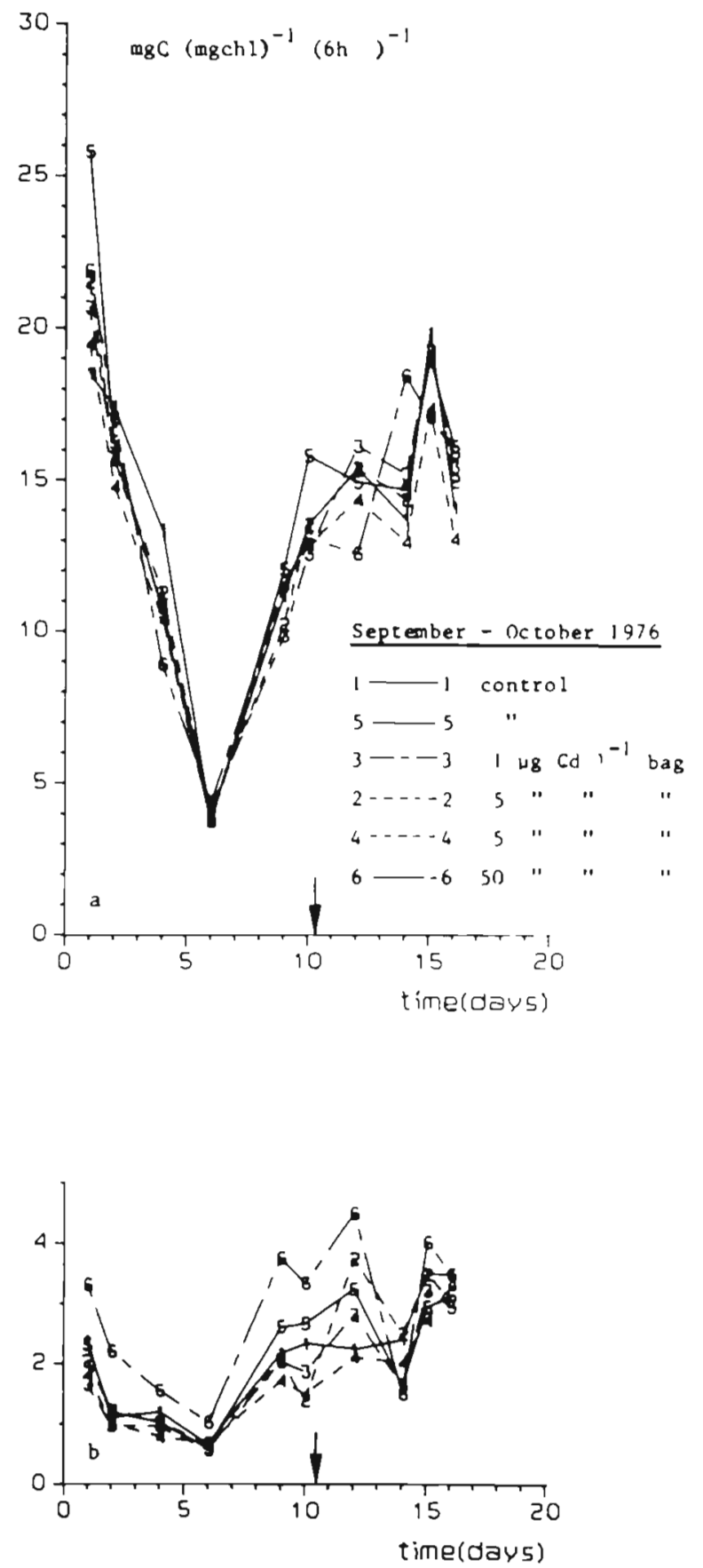

Fig. 4. Carbon assimilation in different bags from 9-15 h during second experiment at depths of 0.5 (a) and $2.0 \mathrm{~m}$ (b) lation was relatively high, but the phytoplankton biomass did not increase much, indicating that a factor other than nutrients limited the phytoplankton increase during this period.

The development of the concentrations of the nutrients is shown in Fig. 5. The first phytoplankton peak depleted the silicate and nitrogen compounds. After this peak, nutrient concentrations remained below the detection limit ( $\mathrm{Si}<1 \mu \mathrm{g}$ at $\mathrm{l}^{-1}, \mathrm{NH}_{4}-\mathrm{N}<0.2 \mu \mathrm{g}$ at $\mathrm{l}^{-1}$, $\mathrm{NO}_{3}-\mathrm{N}<0.1 \mu \mathrm{g}$ at $l^{-1}$ and $\mathrm{NO}_{2}-\mathrm{N}<0.1 \mu \mathrm{g}$ at $\mathrm{l}^{-1}$ ) with the exception of phosphate concentrations which stay around $0.6 \mu \mathrm{g}$ at $\mathrm{Pl}^{-1}$. Nutrients necessary to make phytoplankton growth possible after Day 5 were generated by mineralization of organic matter and used directly (cf. Podamo, 1974).

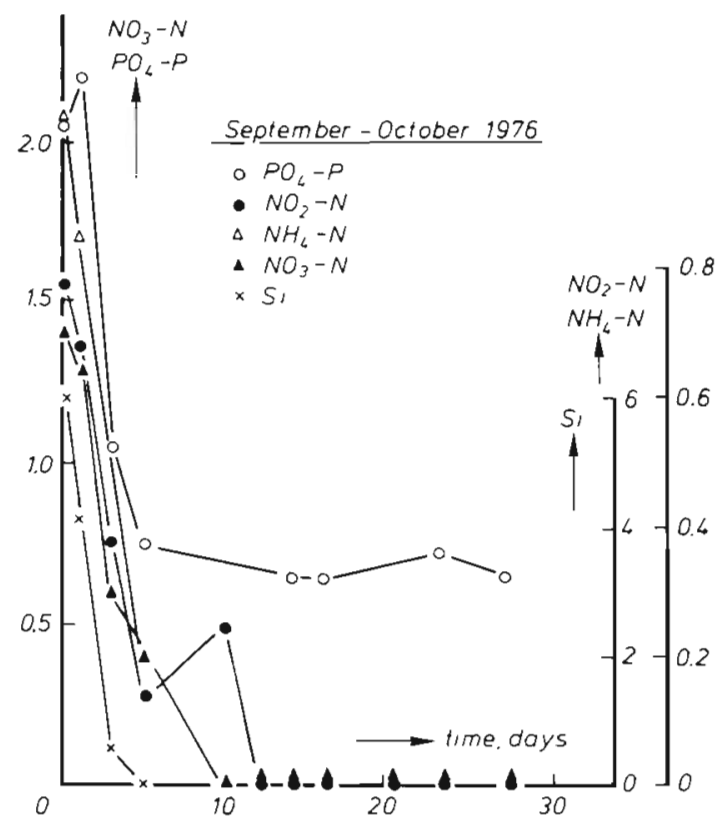

Fig. 5. Concentrations of nutrients during second experiment

\section{Zooplankton During the First Experiment}

The water used to fill the bags contained various zooplankton species; of these, calanoid copepods formed the major part of the biomass. Temora longicornis was the main species, followed by Acartia clausi, Centropages hamatus and Pseudocalanus elongatus. In addition to copepods, larvae of bivalves and worms, and nauplii and cyprids of barnacles were also found. Adult barnacles lived on the bottom of the bag at the end of the experiment.

Figs. 6 and 7 show the development of Temora longicornis and Centropages hamatus during the experiment. From Day 0-23 the average for duplicate bags is

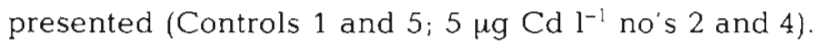
The 2 aforementioned species, and also Acartia clausi, 

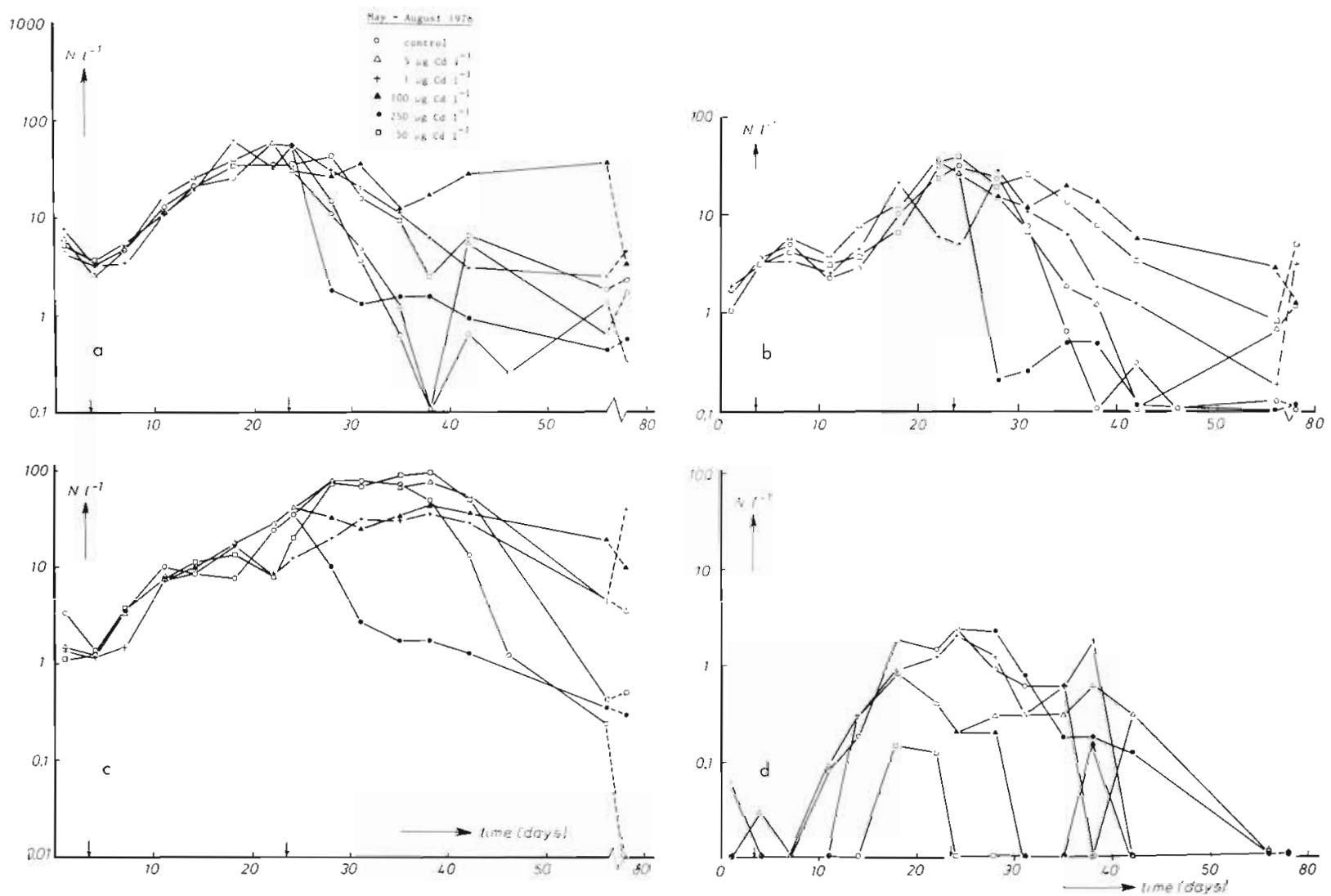

Fig. 6. Temora longicornis. Number of individuals in different bags during first experiment. (a) small nauplii; (b) large nauplıi; (c) copepodites; (d) adults

greatly increased in numbers during the first 40 days of the experiment. Although no eggs were counted, they were definitely produced, since the development time from egg to small nauplius is 1-2 days. These nauplij. developed to copepodites and adults in the bags. During the first 4 weeks there appeared to be continuous production of eggs and a subsequent increase of the numbers of small nauplii. Numbers of nauplii of $T$. longicornis reached a maximum in the controls on Day 22, copepodites on Day 30 and adults on Day 24. For $C$. hamatus maximum numbers of nauplii, copepodites and adults were found on Days 32, 36 and 29 respectively. These data indicate that no clear cohorts could be followed throughout their development. After the

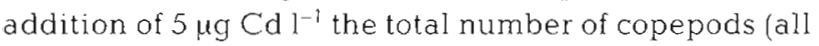
species, all stages) was on the average $19 \%$ higher than in the controls from Day 7-22. After addition of 50

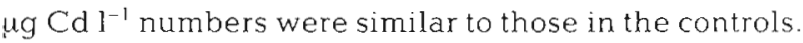

It was not until Day 35 that the cause of these unexpected observations was revealed. It appeared that Pleurobrachia pileus had developed in the controls; this ctenophore is a predator on copepods (Fraser, 1962; Greve, 1970). Fig. 8 shows the number of $P$. pileus in the bags. It is clear that addition of cadmium influences the development of $P$. pileus significantly (test of Wilcoxon, $\mathrm{P} \leqslant 0.05$ ). The number of $P$. pileus

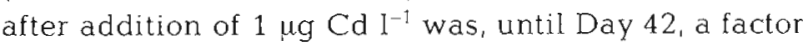
10 lower than in the control. After addition of $5 \mu \mathrm{g} \mathrm{Cd}$ $\mathrm{l}^{-1}$ only 1 ctenophore was found. In bags with cadmium

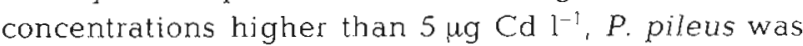
never detected. Addition of $250 \mu \mathrm{g} \mathrm{Cd} . \mathrm{l}^{-1}$ killed most T. longicornis and all C. hamatus. Addition of $100 \mathrm{mg}$

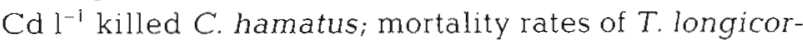
nis (and also of Acartia clausi) increased.

\section{Zooplankton During the Second Experiment}

The water used in the second experiment contained a zooplankton community in which the dominant species was Acartia clausi, followed by Centropages hamatus, Temora longicornis, Euterpina acutifrons, larvae of bivalves and worms, nauplii of barnacles, zoeae of Carcinus sp. and Oikopleura sp. Figs. 9 and 10 show the development of nauplii, copepodites and adults of $A$. clausi and of $C$. hamatus respectively. $T$. longicornis was also present in considerable numbers during the experiment. In the controls the calanoid copepods developed from nauplii to adults. Around Day 20 the nauplii reached maximum densities, $A$ 

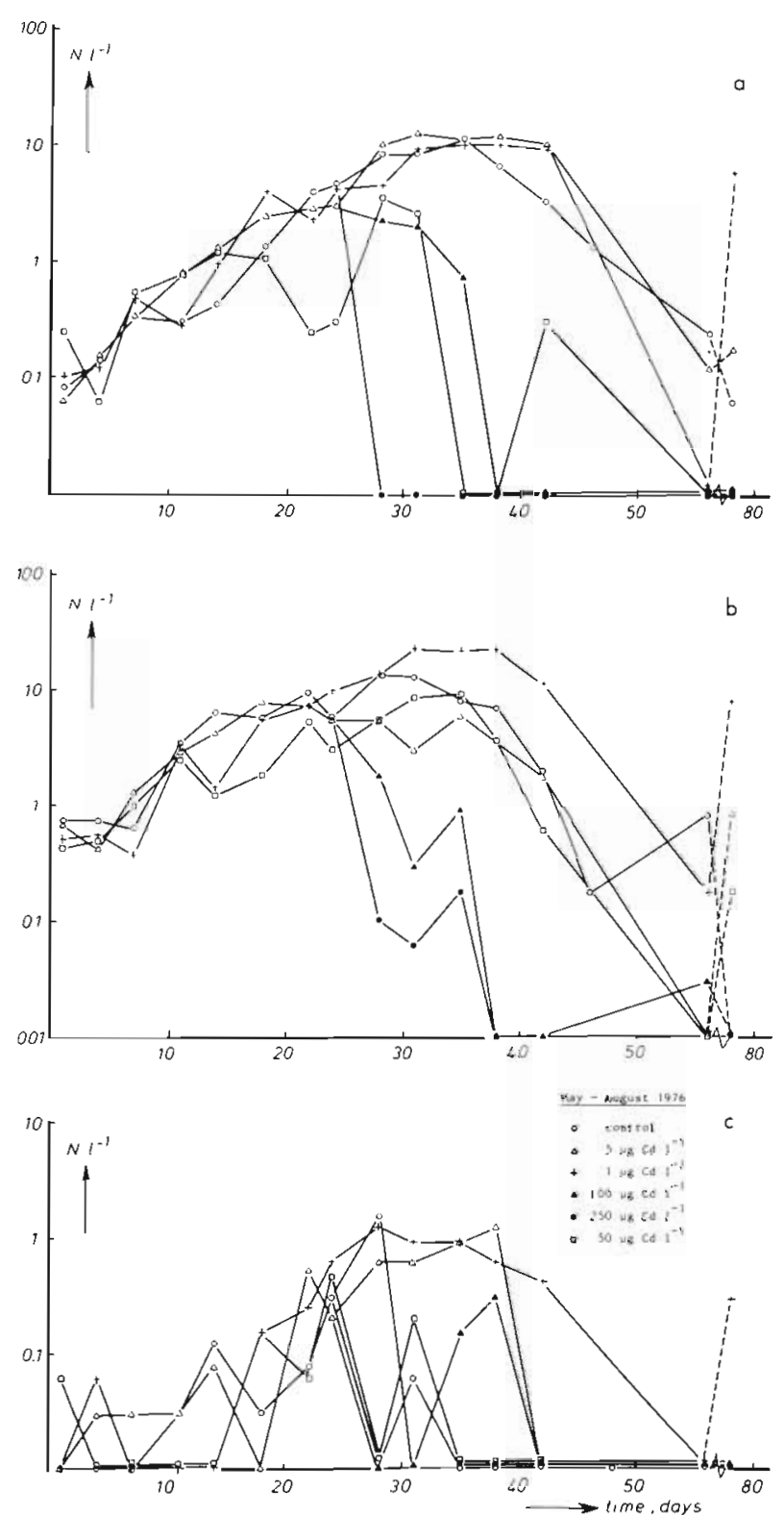

Fig. 7 Centropages hamatus. Number of individuals in different bags during first experiment. (a) nauplii; (b) copepodites; (c) adults. Averages of replicate bags

clausi being the dominant species. In this experiment continuous reproduction also occurred throughout and clear cohorts could not be identified. Addition of 1 or 5 $\mu \mathrm{g} \mathrm{Cd} \mathrm{l}^{-1}$ did not influence the development of the copepods. The number of nauplii of $C$. hamatus was significantly lower than in the controls and the number of copepodites of $C$. hamatus and $A$. clausi was

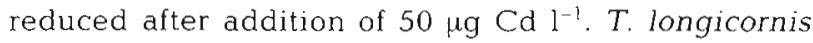
and $E$. acutifrons appeared not to be influenced by 50

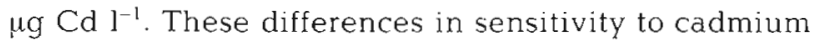
led to shifts in species composition of the zooplankton community. After addition of $50 \mu \mathrm{g} \mathrm{Cd} \mathrm{I}^{-1}, T$. longicor- nis and E. acutifrons were relatively more important than in the controls. Fig. 11 shows the situation in all bags on Day 34.

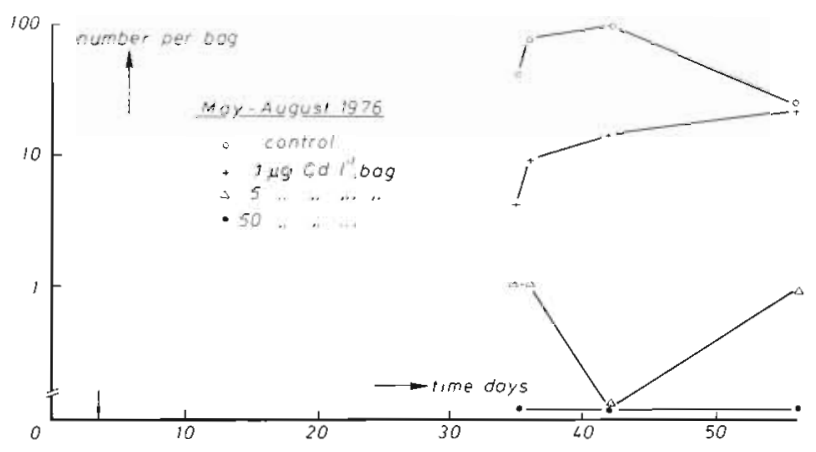

Fig. 8. Pleurobrachia pileus. Number of individuals in different bags during first experiment

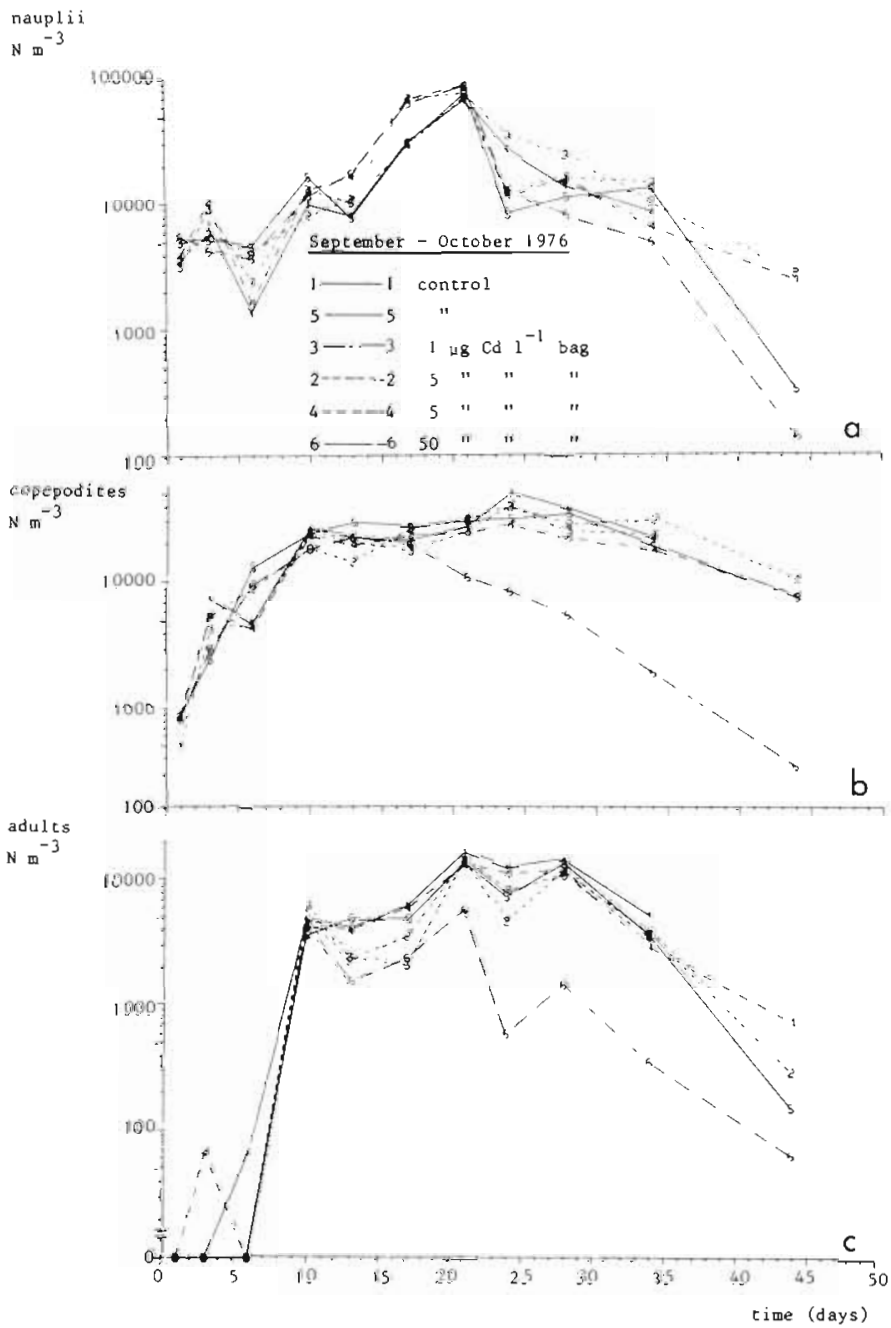

Fig. 9. Acartia clausi. Number of individuals in different bags during second experiment. (d) nauplii; (b) copepodites; (c) adults 


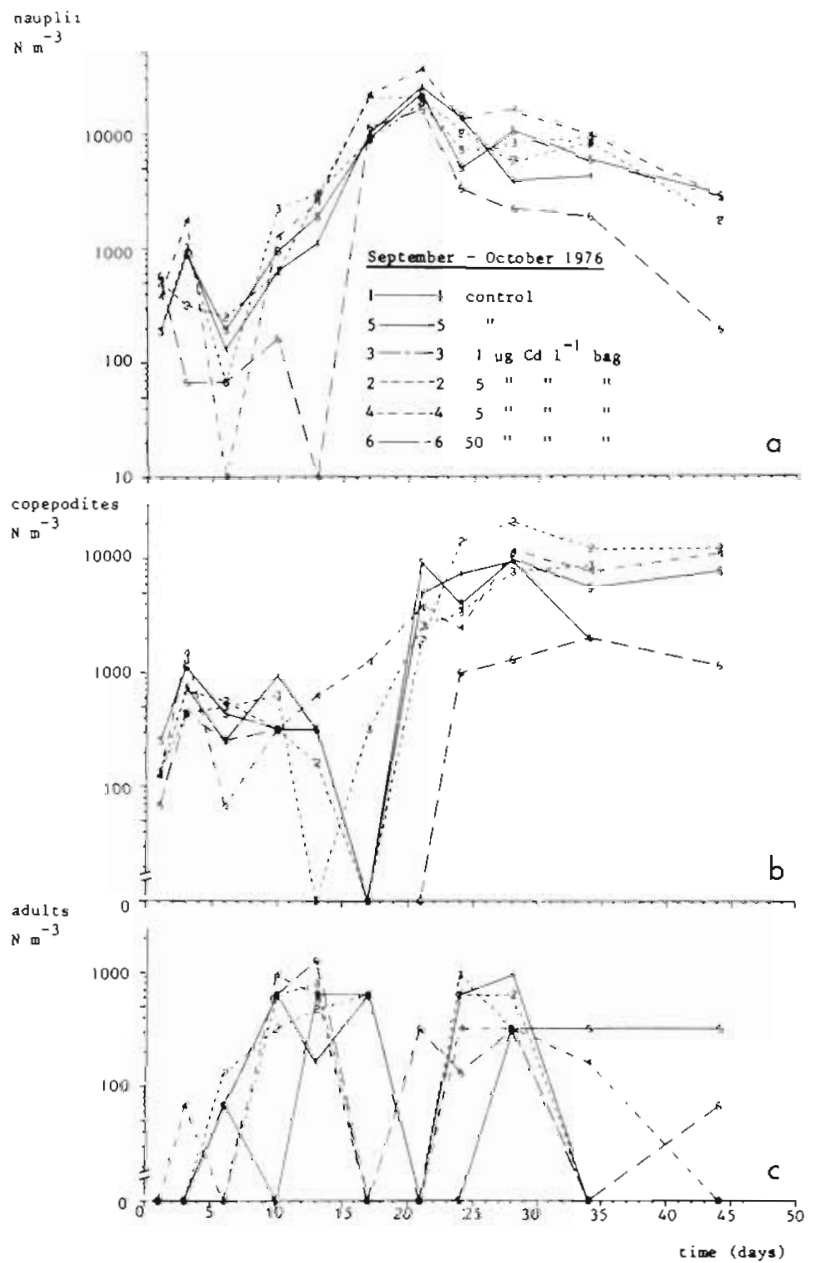

Fig. 10. Centropages hamatus. Number of individuals in different bags during second experiment. (a) nauplii; (b) copepodites; (c) adults

Secondary Production During the Second Experiment

Total secondary production by the calanoid copepods was estimated with the model of Fransz (1976). During the first 3 weeks, secondary production increased from 2 to $20 \mathrm{mg}$ dry weight $\mathrm{m}^{3} \mathrm{~d}^{-1}$ (average of all bags, except Bag $6 ; 50 \mu \mathrm{g} \mathrm{Cd} \mathrm{^{-1 }}$ ). Thereafter, secondary production declined to an estimated average of $10 \mathrm{mg} \mathrm{m}^{-3} \mathrm{~d}^{-1}$. Fig 12 shows the total biomass as a function of time in the different bags as computed from the total numbers of different size classes and length-dry weight relations given by Robertson (1968) and Nassogne (1972). Addition of 1 and $5 \mu \mathrm{g} \mathrm{Cd} \mathrm{l}^{-1}$ did not influence the biomass development, but after addi-

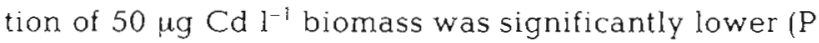
$<0.01$, test of Wilcoxon). Secondary production estimates and biomass data were used to compute the $\mathrm{P} / \mathrm{B}$ ratio (production per day divided by the mean biomass) in the different bags. The $\mathrm{P} / \mathrm{B}$ rations in the

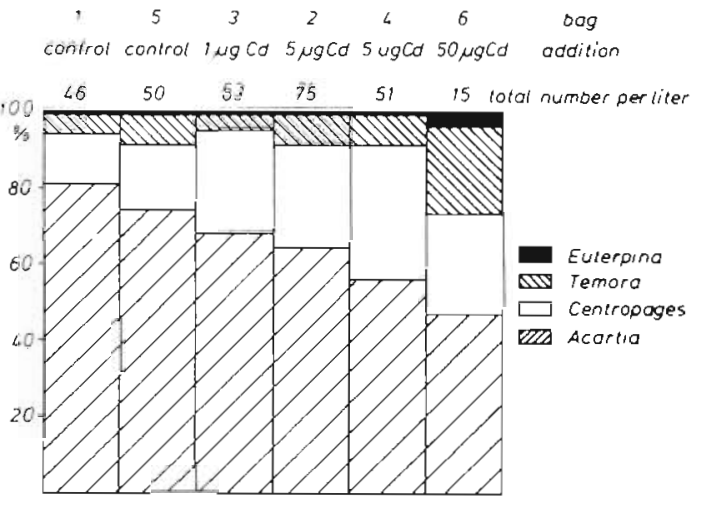

Fig. 11. Relative distribution of different copepod species present on Day 34 in various bags; second experiment

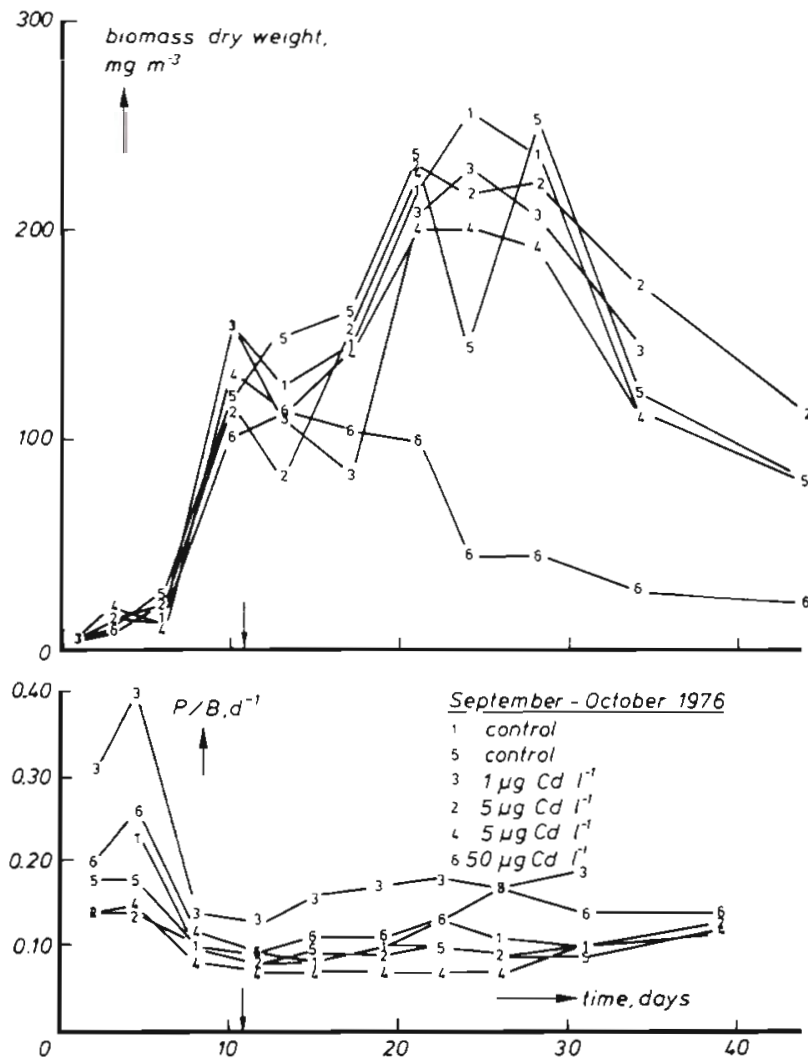

Fig. 12. Secondary production in different bags; second experiment

different bags as a function of time are also presented in Fig. 12. During the first bloom (Day 0-6) maximum $\mathrm{P} / \mathrm{B}$ ratios were found (average $0.21 \pm 0.08, \mathrm{~N}=11$ ).

From Day 10-40 P/B ratios were around 0.11 (standard deviation $0.03, \mathrm{~N}=47$ ). Addition of $50 \mu \mathrm{g} \mathrm{Cd} \mathrm{l}^{-1}$ did not influence the P/B ratio. During the first experiment the same analysis was done using zooplankton data from Day $0-42$. During this period the P/B ratio had 2 maxima. The first maximum was around Day 5 
$(\mathrm{P} / \mathrm{B}=0.22 \pm 0.04, \mathrm{~N}=5)$. The second on Day $21(\mathrm{P} / \mathrm{B}$ $=0.15 \pm 0.09, \mathrm{~N}=4$ ). A minimum $(\mathrm{P} / \mathrm{B}=0.07 \pm 0.02)$ was around Day 12; following the second maximum, $\mathrm{P} /$ $\mathrm{B}$ ratios declined in all bags and from Day 30-40 P/B was $0.07 \pm 0.03$. In both experiments maximum $\mathrm{P} / \mathrm{B}$ ratios occurred during periods of maximum phytoplankton biomass.

Daily primary production during the second experi-

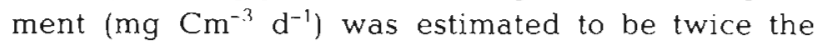
primary production measured at a depth of $0.5 \mathrm{~m}$ or roughly to be 10 times the chlorophyll concentration assuming an average relative carbon assimilation over the water column of $5 \mathrm{mg} \mathrm{C}(\mathrm{mg} \mathrm{chl} \mathrm{a})^{-1}(6 \mathrm{~h})^{-1}$ (Fig. 4). At the beginning of the experiment, primary production was much larger than secondary production, but during the second half of the experiment they were of the same order of magnitude (primary production, $30-$ $50 \mathrm{mg} \mathrm{Cm}^{-3} \mathrm{~d}^{-1}$; secondary production $10 \mathrm{mg} \mathrm{Cm}^{-3}$ $\left.\mathrm{d}^{-1}\right)$.

Using filtration rates given by Sonntag and Parsons

Table 1. Total volumes filtered by copepods in different bags during second experiment. Filtration rates: nauplii, $0.5 \mathrm{ml}$ $\mathrm{d}^{-1}$; small copepodites, $10 \mathrm{ml} \mathrm{d}^{-1}$; large copepodites, $25 \mathrm{ml}$ $\mathrm{d}^{-1} ;$ adults, $40 \mathrm{ml} \mathrm{d}^{-1}$

\begin{tabular}{|rcccccc|}
\hline \multicolumn{6}{|c|}{ Filtered volume $\left(\mathrm{m}^{3} \mathrm{~m}^{-3} \mathrm{~d}^{-1}\right)$} \\
Day & Controls & $\begin{array}{c}1 \mu \mathrm{g} \\
\mathrm{Cd} \mathrm{^{-1 }}\end{array}$ & $\begin{array}{c}5 \mu \mathrm{g} \\
\mathrm{Cd} \mathrm{l}^{-1}\end{array}$ & $\begin{array}{c}50 \mu \mathrm{g} \\
\mathrm{Cd} \mathrm{l}^{-1}\end{array}$ \\
\hline 3 & 0.11 & 0.05 & 0.07 & 0.09 & 0.11 & 0.05 \\
10 & 0.83 & 0.70 & 0.84 & 0.64 & 0.73 & 0.58 \\
17 & 0.80 & 0.87 & 0.51 & 0.83 & 0.80 & 0.60 \\
21 & 1.30 & 1.37 & 1.21 & 1.29 & 1.19 & 0.50 \\
28 & 1.44 & 1.40 & 1.12 & 1.26 & 1.08 & 0.20 \\
34 & 0.69 & 0.63 & 0.81 & 0.95 & 0.59 & 0.11 \\
\hline
\end{tabular}

Table 2. Concentrations of cadmium in sediment of different bags at end of experiments

\begin{tabular}{|cccc|}
$\begin{array}{c}\text { Bag } \\
\text { no. }\end{array}$ & $\begin{array}{c}\text { Cd added } \\
\text { to bag }(\mathrm{mg})\end{array}$ & $\begin{array}{c}\text { Cd concentration } \\
\left(\mathrm{mg} \mathrm{kg} \mathrm{kg}^{-1} \text { ) }\right. \\
\text { weight basis }\end{array}$ & $\begin{array}{c}\% \text { of added } \\
\text { Cd in } \\
\text { sediment }\end{array}$ \\
\hline $\begin{array}{c}\text { 1st experiment } \\
1\end{array}$ & 0 & 1.4 & - \\
2 & 7 & 28.6 & 7.3 \\
3 & 1.4 & 4.8 & 5.6 \\
4 & 147 & 440.0 & 7.3 \\
5 & 350 & 1110.0 & 7.3 \\
6 & 70 & 362.0 & 9.2 \\
2 nd experiment & & \\
1 & 0 & 1.2 & - \\
2 & 7 & 18.4 & 5.0 \\
3 & 1.4 & 4.6 & 4.1 \\
4 & 7 & 26.1 & 4.6 \\
6 & 70 & lost during analysis \\
\hline
\end{tabular}

(1979), the volume filtered by the copepods per day can be computed from the densities of the copepods. Table 1 shows the results of these computations. During the period with maximum densities of nauplii and copepodites (Day 20-30) the water in the bags was filtered totally more than once per day The estimates of secondary production and filtration rates, indicate the large influence of grazing zooplankton in this experiment. During the second half of the experiment development of phytoplankton biomass appeared to be prevented by the grazing pressure.

\section{Fate of the Added Cadmium Chloride}

Fig. 1 shows cadmium concentrations in the water during the first experiments; similar results were obtained in the second experiment. Most of the added cadmium remains in the water phase. Table 2 lists the cadmium concentrations in the sediment on a wet weight basis, and the amount of cadmium present in the sediment at the end of the 2 experiments. In the first experiment $7.3 \%$ of the added cadmium was found in the sediment on Day 93; in the second, $4.6 \%$ on Day 48.

\section{DISCUSSION}

\section{Fate of the Added Cadmium}

The cadmium added to the bags remained in the system and accumulated very slowly in the sediment due to adsorption and subsequent settling of suspended particles (abiotic particles, phytoplankton cells, dead zooplankton, etc.). Adsorption to walls was negligible. Adsorption of cadmium to particles is much less pronounced in sea water than in fresh water. This is probably due to the formation of stable $\mathrm{CdCl}_{2}$ in sea water (Hahne and Kroontje, 1973; Bryan, 1976, Raspor et al., 1977). Preston et al. (1972) state that $18 \%$ of the total cadmium concentration found in a series of samples from British coastal waters was bound to the particulate fraction, a high estimate compared with those of other authors. Eaton (1976) found that on the average less than $0.4 \%$ of the total cadmium was bound to the praticulate fraction $(>0.45 \mu)$. In our experiments unfiltered water samples were analyzed, so that no information on the distribution of cadmium in the water is available.

Ketchum et al. (1975) have also reported very constant cadmium levels after addition of cadmium to marine micro ecosystems containing sediments. Kremling et al. (1978) performed 2 experiments with plankton communities enclosed in $68 \mathrm{~m}^{3}$ bags to which 
$1.3 \mu \mathrm{g} \mathrm{Cd} \mathrm{l} \mathrm{'} \mathrm{was} \mathrm{added} \mathrm{Cadmium} \mathrm{concentrations} \mathrm{in}$ the water were nearly constant and at the end of the experiments less than $1 \%$ was found in the sediments. In our experiments the amount of cadmium recovered in the sediment was higher; this is probably due to the longer duration of the experiments and the higher productivity of the enclosed plankton community.

\section{Effects of Cadmium on Phytoplankton}

Addition of cadmium chloride to the enclosed micro ecosystem had the following impact on the phyto-

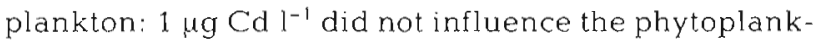

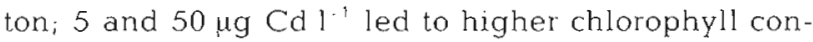
centrations in the first experiment. In the second experiment, 5 and $50 \mu \mathrm{g} \mathrm{Cd}^{-1}$ did not influence the phytoplankton. The species composition was not

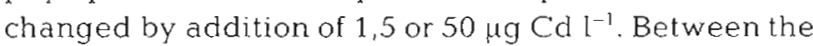
2 experiments a short (11d) experiment was performed, using the same methods, in which higher chlorophyll concentations were found after addition of 5 or $50 \mu \mathrm{g} \mathrm{Cd} \mathrm{l}^{-1}$, due to growth of Chaetoceros spp. (Kuiper, 1980)

In model ecosystems, higher chlorophyll concentrations can be the result of less removal from the water due to less predation by herbivores, lower sinking rates (e.g. caused by a different species composition of the community) or can be caused by increased growth. Lower sinking rates seem improbable since the species composition was the same in all systems, and since physical factors (turbulence, light) were the same in

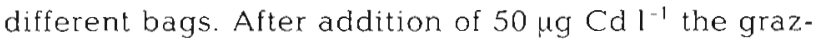
ing pressure may have been lower, resulting from inhibition of the development of the copepods. In the short, lower numbers of copepods were found after addition of $50 \mu \mathrm{g} \mathrm{Cd} \mathrm{^{-1 }}$ Lower grazing pressure after addition of $5 \mu \mathrm{g} \mathrm{Cd}{ }^{1}$ seems improbable, since in the bags concerned even higher numbers of copepods were found than in the controls, due to less grazing by Pleurobrachia pileus. The possibility that addition of $5 \mu \mathrm{g} \mathrm{Cd} \mathrm{l^{-1 }}$ stimulated phytoplankton growth cannot therefore be excluded, although the working mechanisms are unclear

Tkachenko et al. (1974) found stimulation of phytoplankton growth, measured as carbon assimilation, after addition of $1-10 \mu \mathrm{g} \mathrm{Cd}{ }^{-1}$ to natural phytoplankton assemblages. Berland et al. (1977) report increased growth rates of Skeletonema costatum during the first day after addition of $25-100 \mu \mathrm{g} \mathrm{Cd} \mathrm{l}^{-1}$; other investigators have also reported growth stimulation after addition of cadmium to diatom cultures (Canterford et a1., 1978) or natura! phytoplankton assemblages (Patin et al., 1972 Ibragim and Patin, 1975) On Day 23 of the first experiment additional doses of 100 and $250 \mu \mathrm{g}$ $\mathrm{Cd} \mathrm{I}^{-1}$ were added to 2 bags. Because the frequency of sampling was much lower after Day 24 than before, and because the interactions between the different trophic levels became increasingly complicated (see section on Zooplankton), it was not possible to show a significant influence of the addition of these higher cadmium concentrations on the chlorophyll concentrations. The third maximum in the control and the bags to which 1,5 or $50 \mu \mathrm{g} \mathrm{Cd} \mathrm{^{-1 }}$ was added, occurred on Day 46, in the bag to which $250 \mu \mathrm{g} \mathrm{Cd}^{-1}$ was added on Day 42 . The fact that this maximum occurred earlier after addition of 100 and $250 \mu \mathrm{g} \mathrm{Cd} \mathrm{l-1} \mathrm{might} \mathrm{be} \mathrm{a}$ result of mineralization of dead zooplankton or reduced grazing

The lowest concentrations influencing the growth of

Table 3. Minimum concentratıons exertıng effects on marme anımals. Based on the sources listed

\begin{tabular}{|c|c|c|c|}
\hline Species & $\begin{array}{l}\text { Concentration } \\
\left(\text { ug } \mathrm{Cd} \mathrm{l}^{-1}\right)\end{array}$ & Effect & Source \\
\hline Tigriopus japonicus & 44 & $\begin{array}{l}\text { Time to reach } F 2 \text { generation more } \\
\text { than doubled }\end{array}$ & D'Agostino and Finney (1974) \\
\hline Uca pugilator & 1 & $\begin{array}{l}\text { Decredsed swimming artivity of zoed } \\
\text { Stage I, reduced salinity and tenupeldture } \\
\text { toleranc'; depressed respiration of } \\
\text { Zoed } V\end{array}$ & Vornberg et al. (1974) \\
\hline Pleuronectes flesus & 5 & Blood anemid & Larsson $(197.5)$ \\
\hline Homarus americanus & 6 & Increased oxygen consumption & Thurberg et al (1977) \\
\hline Morone saxatilis & $0.5-5$ & Depressed oxygen consumption & Calabrese el al. (1977) \\
\hline Palaemonetes pugio & 44 & $50 \%$ mortality & Sunda et al. (1978) \\
\hline Eurypanopeus depressus & 10 & Decreased development rate & Mirkes el al. (1978) \\
\hline Pleuronectus platessa & 5 & Reduced growth & Westernhagen et al (1978) \\
\hline Mysidopsis bahia & 10 & $\begin{array}{l}\text { Reduced curvival; reduced formation } \\
\text { of brood pouches }\end{array}$ & Nimmo et al. (1978) \\
\hline Mytllus edulis & 50 & Reduced development of Trochophora & Lehnberg and Therde (1979) \\
\hline Laomedea edulis & 3 & Irreversible retraction of hydranths & Therede et al. (1979) \\
\hline Pseudodiaptomus coronatus & 1 & Reduced feeding rates & Sick and Baptist (1979) \\
\hline
\end{tabular}


fresh water phytoplankton found in the literature vary from 2-50 ug Cd l' (Hutchinson, 1973; Bartlett et al., 1974; Klass et al., 1974; Conway, 1978). Berland et al. (1976) investigated the influence of cadmium chloride on 18 marine species. Growth rate-inhibiting concentrations varied from $5-500 \mu \mathrm{g} \mathrm{Cd} l^{1}$ (mean $85 \mu \mathrm{g}$ $\mathrm{Cd} \mathrm{l}^{-1}$ ), lethal concentrations for 16 of the 18 species were equal to or higher than $250 \mu \mathrm{g} \mathrm{Cd} \mathrm{l} \mathrm{'.} \mathrm{Li} \mathrm{(1978)}$ and Hollibaugh et al. (1980) recorded growth rate inhibition after addition of $100 \mu \mathrm{g} \mathrm{Cd} \mathrm{L} \mathrm{'.} \mathrm{Tkachenko} \mathrm{et}$ al. (1974) found inhibition of several marine phyto-

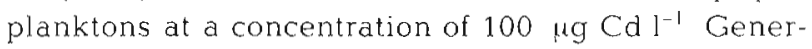
ally, inhibition of phytoplankton appears to occur at lower cadmium concentrations in fresh water than in the marine environment. The differences in speciation of cadmium in fresh and salt water are probably responsible for this difference. Due to the much lower adsorption in seawater, the a mount of cadmium which reaches the cell is lower in seawater than in fresh water with the same cadmium concentration and cell density

The differences in the response of the phytoplankton in the 2 experiments could be due to any of a number of factors. Firstly, starting conditions differed widely between experiments (species composition, nutrient concentrations, etc.). Secondly, in the first experiment cadmium was added before large phytoplankton blooms had occurred and nutrients were not depleted; in the second experiment cadmium was added just after a bloom. Under these circumstances dying phytoplankton probably supplied large amounts of organic compounds able to complex the added cadmium Härdstedt-Roméo and Gnassia-Barelli (1980) showed that organic substances produced by phytoplankton cells can decrease the amounts of cadmium taken up by phytoplankton.

\section{Effects of Cadmium on the Zooplankton}

During the first experiment addition of cadmium inhibited the development of Pleurobrachia pileus at all concentrations $\left(1-250 \mu \mathrm{g} \mathrm{Cd}^{-1}\right)$. After addition of $1 \mu \mathrm{g} \mathrm{Cd} 1^{1}$ the numbers of this ctenophore were 10 times lower than in the control; after addition of $5 \mu \mathrm{g}$

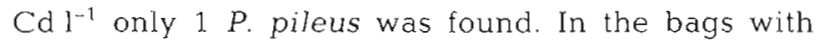
cadmium concentrations of $50 \mu \mathrm{g} \mathrm{Cd}^{-1}$ or more $P$. pileus was never found. Unfortunately, by the time $P$. pileus was observed, no replicate bags were available,

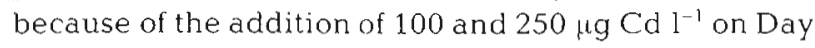
23. However, the fact that during the first period numbers of copepods in the 2 controls were lower than in the bags to which $5 \mu \mathrm{g} \mathrm{Cd} \mathrm{C}^{1}$ had been added (the numbers were on average even lower in the control bag which was later sacrificed), indicates that also during the first period the grazing pressure of $P$. pileus was more intense in controls than in bags with $5 \mu \mathrm{g}$ ${\mathrm{Cd} 1^{-1}}^{-1}$

The increased mortality rate of copepods in the controls due to grazing Pleurobrachia pileus makes demonstration of a possible increase in mortality rates resulting from addition of cadmium more difficult (cf. Gibson and Grice, 1977). Addition of $250 \mu \mathrm{g} \mathrm{Cdl}{ }^{1}$ killed most Temora longicornis and all Centropages hamatus. Addition of $100 \mu \mathrm{g} \mathrm{Cd} \mathrm{l}{ }^{1}$ killed C. hamatus and increased mortality rates of $T$. Jongicornis (and also of Acartia clausi). At the beginning of the experiment, numbers of copepods, following addition of $50 \mu \mathrm{g} \mathrm{Cd} \mathrm{l}^{-1}$, were comparable to or lower than in the controls. In the controls a certain grazing pressure existed because of developing $P$. pileus. It may there-

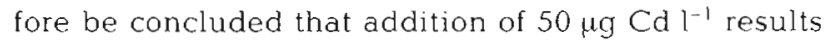
in increased mortality of copepods or a decreased development rate.

In the second experiment the effects of cadmium

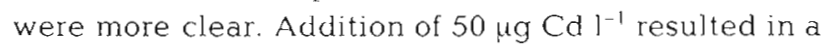
much lower biomass of copepods than in the controls. Not all species of copepods were influenced; this led to changes in species composition, compared to controls. In nature such shifts in species composition may exert important effects on higher trophic levels via selective feeding

In both experiments no significant influence on the development of copepods after addition of 1 and $5 \mu \mathrm{g}$ could be shown. Recent literature reveals a decrease of no-effect levels with time. Eisler (1971), reviewing the toxicity of cadmium to marine organisms, reports that some crustacean species were most sensitive, having $96 \mathrm{~h}$ LC 50 values of $320-420 \mu \mathrm{g} \mathrm{Cd}{ }^{-1}$. According to Pavicic and Järvanpäa (1974) the development of Mytilis galloprovincialis veligers was inhibited by $80 \mu \mathrm{g} \mathrm{Cd} \mathrm{l}^{-1}$. Rosenberg and Costlow (1976) reported that $50 \mu \mathrm{g} \mathrm{Cd}{ }^{\prime}$ decreased the survival and development rate of some development stages of 2 estuarine crabs; $50 \mu \mathrm{g} \mathrm{Cd} \mathrm{l}^{-1}$ was the lowest concentration exerting adverse effects on marine animals. Reviews by Taylor (1977) and Davies (1978) also list very few effects from cadmium concentrations lower than $50 \mu \mathrm{g}$ $\mathrm{Cd} \mathrm{I}^{-1}$. Taylor (1977) concludes that the range containing $90 \%$ of the literature data in sublethal effects to

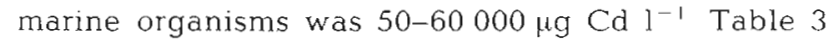
lists additional effects of cadmium concentrations on marine animals. In fresh water, adverse effects of cadmium seem to occur at lower concentrations (Biesinger and Christensen, 1972; Pascoe and Mattey 1977; Taylor, 1977). The different speciation of cadmium in fresh water is probably also here the key factor for causing this difference. The cadmium concentrations influencing the development of copepods and Pleurobrachia pileus in the present report are among the lowest 
reported in the literature. Other investigators reporting effects of cadmium at concentrations $<5 \mu \mathrm{g} \mathrm{Cd}{ }^{-1}$ mostly employed flow-through systems, in which cadmium was refreshed and probably remained in a noncomplexed form. In the bags part of the cadmium was presumably complexed by organic compounds, and therefore less available for the biota. The importance of speciation of metals in relation to their toxicity and bioaccumulation is increasingly acknowledged and has also been shown for cadmium. For example, Premazzi et al. (1978) documented a 5 fold increase of the EC 50 of cadmium to Selenastrum if EDTA was present, and Sunda et al. (1978) showed that the free cadmium is mainly responsible for toxic effects.

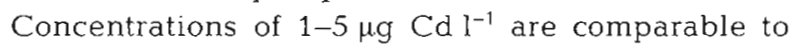
those occurring locally in the field; Bryan (1976) gives $0.04 \mu \mathrm{g} \mathrm{Cd}^{-1}$ as the mean concentration in the N.E.

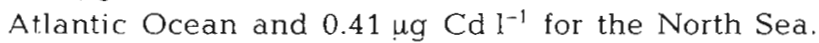
Boyden et al. (1979) found concentrations around 0.4 $\mu \mathrm{g} \mathrm{Cd} 1^{-1}$ in a Cornish estuary. Nürnberg and Valenta

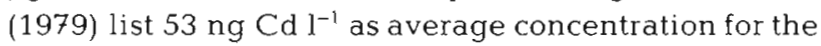
North Sea, being 10 times lower than our figures and those of Bryan (1976); this probably can be attributed to differences in the analytical method used. Eaton (1976) found a mean of $60 \mathrm{ng} \mathrm{Cd}{ }^{-1}$ in the Atlantic Ocean and $230 \mathrm{ng} \mathrm{l}^{-1}$ in the Gulf of Maine. In polluted coastal waters, such as the Bristol Channel or Scheldt estuary, concentrations can be as high as $10 \mu \mathrm{g} \mathrm{Cd} \mathrm{l}^{-1}$ (Abdullah, 1972); Holmes et al. (1974) even measured $78 \mu \mathrm{g} \mathrm{Cdl^{-1 }}$ in an estuary in Texas; maxima of 20-80 $\mu \mathrm{g} \mathrm{Cd} \mathrm{l}^{-1}$ were recorded by Kneip (1977) near

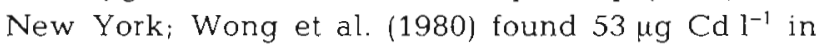
Hong-Kong waters.

\section{CONCLUSIONS}

The cadmium added to the bags remained in the experimental system and accumulated very slowly $\left(<1 \%\right.$ week $\left.\mathrm{k}^{-1}\right)$ into the sediment, which collected on the bottom of the bags.

Addition of single doses of 5 and $50 \mu \mathrm{g} \mathrm{Cd} \mathrm{l}^{-1}$ resulted in higher phytoplankton biomass compared to controls in the first experiment. In the second experiment, no effects on phytoplankton were detected. In both experiments the species composition of the phytoplankton was not influenced after addition of 1,5 or $50 \mu \mathrm{g} \mathrm{Cd} \mathrm{l}^{-1}$.

During the first experiment, addition of cadmium inhibited the development of Pleurobrachia pileus at all concentrations $\left(1-250 \mu \mathrm{g} \mathrm{Cd} \mathrm{l^{-i }}\right)$. At concentrations of $50 \mu \mathrm{g} \mathrm{Cd} \mathrm{l^{-1 }}$ or higher $P$. pileus did not develop in the bags. The presence of $P$. pileus influenced the development of the copepods in such a way that the densities of copepods after addition of 1 and $5 \mu \mathrm{g} \mathrm{Cd} l^{-1}$ were higher than in the controls. In the second experiment addition of 1 and $5 \mu \mathrm{g} \mathrm{Cd} \mathrm{l^{-1 }}$ did not influence the

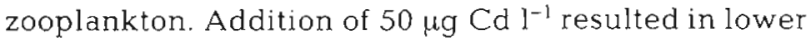
zooplankton biomass and a different species composition as compared with the controls. Addition of 100 and $250 \mu \mathrm{g} \mathrm{Cd} \mathrm{l}^{-1}$ increased the mortality rate of the copepods.

Although the single dose of cadmium, added to the bags, was probably complexed during the experiment, so that only a limited amount of 'biologically active' cadmium was present in the waterphase, concentrations influencing the development of copepods and Pleurobrachia pileus are among the lowest reported in literature. These concentrations are comparable to those occurring locally in polluted water, indicating that in these waters cadmium may already have a detrimental influence on the ecosystem.

Achnowledgements. This work was carried out under contract no. 227-77-1 ENV N of the EEC Environmental Research Programme. Thanks are due to my colleagues W. C. de Kock, M. Dogger-Rutten, G. Hoornsman, J. A van Noort-Koeman, P. Roele, B. Schrieken, J. van de Eikhoff, K. van de Togt, H. van het Groenewoud and L. Wittebrood, who helped with the chemical, biological and statistical analysis and with evaluating the results. J. J. Formsma, D. Pompert and S. Visser are also thanked for their assistance. Help by other colleagues at Delft is also acknowledged. I further like to thank Drs. G. C. Cadée, H. G. Fransz and W W. C. Gieskes of The Netherlands Institute of Sea Research for help and advice. Finally, I thank the authorities of the Royal Dutch Navy for kind cooperation in supplying experimental facilities. P. B. Davis corrected my English manuscript.

\section{LITERATURE CITED}

Abdullah, M. J., Royle, L. G., Morris, A. W (1972). Heavy metal concentration in coastal waters. Nature, Lond. 235 $158-160$

Anderson, G. C., Zeutschel, R. P. (1970). Release of dissolved organic matter by marine phytoplankton in coastal and offshore areas of the N. E. Pacific Ocean. Limnol. Oceanogr 15: 402-407

Bartlett, L., Rabe, F. W., Funk, W. H. (1974). Effects of copper, zinc and cadmium on Selanastrum capricornutum. Wat. Res. 8: 179-185

Bennekom, A. J., van, Gieskes, W W. C., Tijssen, S. B. (1975). Eutrophication of Dutch coastal waters. Proc. R. Soc. Lond. B 189: 359-374

Berland, B. R., Bonin, D. J., Guérin-Ancey, O. J., Kapkov, V. I., Arlhac, D. P. (1977). Action de métaux lourds à des doses sublethales sur les caractéristiques de la croissance chez la diatomée Skeletonema costatum. Mar Biol. 42: 17-30

Berland, B. R., Bonin, D. J., Kapkov, V l., Maestrini, S. Y., Arlhac, D. P. (1976). Action toxique de quatre métaux lourds sur la croissance d'algues unicellulaires marines. C. r. hebd. Séanc. Acad. Sci., Paris (Serie D) 282: 633-636

Biesinger, K. E., Christensen, G. M. (1972). Effects of various metals on survival growth, reproduction and metabolism of Daphnia magna. J. Fish. Res. Bd Can. 29: 1691-1700

Boyden, C. R., Aston, S. R., Thornton, I. (1979). Tidal and seasonal variations of trace elements in two Cornish estuaries. Estuar coast. mar Sci. 9: 303-317 
Bryan, G. W. (1976). Heavy metal contamination in the sea. In: Johnston, R. (ed.) Marine pollution. Academic Press, London, New York, San Francisco, pp. 185-302

Calabrese, A., Thurberg, F. P., Gould, E. (1977). Effects of cadmium, mercury and silver on marine anımals. Mar. Fish. Rev. 39: 511

Canterford, G. C., Buchanan, A. S., Ducker, S. C. (1978). Accumulation of heavy metals by the marine didtom Dytilum brightwelli (West) Grunov. Aust. J. mar Freshwat. Res. 29: 613-622

CEC (1974). Problems of the contamination of man and his environment by mercury and cadmium, Commission of the European Communities, Luxembourg

Conway, H. L. (1978). Sorption of arsenic and cadmium and their effects on growth, micronutrient utilization, and photosynthetic pigment composition of Asterionella formosa. J. Fish. Res. Bd Can. 35: 286-294

D'Agostino, A., Finney, C. (1974). The effect of copper and cadmium on the development of Tigriopus japonicus. In: Vernberg, F. J., Vernberg, W B. (eds.) Pollution and physiology of marine organisms. Academic Press, London, New York and San Francisco, pp. 445-463

Davies, A. G. (1978). Pollution studies with marine plankton. Part II. Heavy metals. Adv. mar Biol. 15: 381-508

Davies, J. M., Gamble, J. C. (1979). Experiments with large enclosed ecosystems. Phil. Trans. R. Soc. Lond. B 286: $523-544$

Drebes, G. (1974). Marınes Phytoplankton, Georg Thieme Verlag, Stuttgart

Eaton, A. (1976). Marine geochemstry of cadmium. Mar Chem. 4: 141-154

Eisler, R. (1971). Cadmium poisoning in Fundulus heteroclitus (pisces, Cyprinodontidae) and other organism. J. Fish. Res. Bd Can. 28: 1225-1234

Fonds, A. W., Estrof, A. J. (1973). Bepaling van sporen lood, koper, zink, cadmium, nikkel, kobalt, mangaan en ijzer in water d. m. v. gelijktijdige extractie en atoomabsorptiespectrofotometrie $\mathrm{H}_{2} \mathrm{O}$ 18: 465-467

Fransz, H. G. (1976). The spring development of calanoid copepod populations in the Dutch coastal waters as related to primary production. Proc. 10th Eur. Symp. Mar Biol. Ostend, Vol. 2: 247-269

Fraser, J. H. (1962). The role of ctenophores and salps in zooplankton production and standing crop. Rapp. P. Réun. Cons. perm. int. Explor Mer 153: 121-123

Gamble, J. C., Davies, J. M., Steele, J. H. (1977). Loch Ewe Bag experiment, 1974. Bull. mar Sci. 27: 146-175

Gibson, V R., Grice, G. D. (1977). Experimental observations on the effects of copper on copepods and other zooplankton: controlled ecosystem pollution experiment. Bull. mar Sci. 27: 85-91

Greve, W $(1970)$. Cultivation experiments on North Sea ctenophores. Helgoländer wiss. Meeresunters. 20: $304-317$

Hahne, H. C. H., Kroontje, W. (1973). Significance of $\mathrm{pH}$ and chloride concentrations on behaviour of heavy metal pollutants: Mercury (II), cadmium (II), zinc (II) and lead (II). J. Environ. Qual. 2: 444-450

Härdstedt-Roméo, M., Gnassia-Barelli, M. (1980). Effect of complexation by natural phytoplankton exudates on the accumulation of cadmium and copper by the Haptophyceae Cricosphaera elongata. Mar. Biol. 59: 79-84

Hollibaugh, J. T., Seibert, D. L. R., Thomas, W H. (1980). A comparison of the acute toxicities of ten heavy metals to phytoplankton from Saanich Inlet, B. C. Canada. Estuar. coast. mar. Sci. 10: 93-105

Holmes, C. W., Slade, E. A., McLerran, C. J. (1974). Migration and redistribution of $\mathrm{Zn}$ and $\mathrm{Cd}$ in estuarine system. Environm. Sci. Technol. 8: 255--259

Hutchinson, T. C. (1973). Comparative studies on the toxicity of heavy metals to phytoplankton and their synergistic Interactions. Water pollution research in Canada, Univ. Toronto, Inst. Environ. Sci. Eng. 8: 68-90

Ibragim, A. M., Patin, S. A. (1975). Effect of mercury, lead, cadmium and copper on primary production and phytoplankton in some coastal regions of the Mediterranean and read seas. Oceanology (Moscow) 15: 589-591

Ingram Hendey, N. (1964). An introductory account of the smaller algae of Britısh coastal waters. Part V: Bacillariophyceae (diatoms). Her Majesty's Stationary Office, London

Ketchum, B. H., Zitko, V., Saward, D. (1975). Aspects of heavy metal and organohalogen pollution in aquatic ecosystems. In: McIntyre, A. D., Hills, C. F. (eds.) Ecological toxicology research. Effects of heavy metals and organohalogen compounds. Plenum Press, New York and London, pp. 75-90

Klass, E., Rowe, D. W., Massaro, E. J. (1974). The effect of cadmium on population growth of the green alga Scenedesmus quadricauda. Bull. Environm. Contam. Toxicol. 12: 442-445

Kneip, T. J. (1977). Effects of cadmium in an aquatic environment. Metal Bull., Proc. 1st Int. Cadmium Conference, San Francisco, pp. 120-124

Kremling, K., Piuze, J., von Bröckel, K., Wong, C. S. (1978) Studies on the pathways and effects of cadmium in controlled ecosystem enclosures. Mar Biol. 48: 1-10

Kuiper, J. (1977a). Development of North Sea coastal plankton communities in separate plastic bags under identical conditions. Mar Biol. 44: 97-107

Kuiper, J. (1977b). An experimental approach in studying the influence of mercury on a North Sea coastal plankton community. Helgoländer wiss. Meeresunters. 30: 652-665

Kuiper, J. (1980). Continued investigations into pelagic microcosms subject to environmental stress by pollutants. II. Cadmium. Report MT-TNO no. CL 80/31, 72 pp.

Kuiper, J. (1981). Fate and effects of mercury in marine plankton communities in experimental enclosures. Ecotoxicol. Envir. Safety 5: 106-134

Larsson, A. (1975). Some biochemical effects of cadmium on fish. In: Koeman, J. H., Strik, J. J T W. W. (eds.) Sublethal effects of toxic chemical on aquatic animals. Elsevier, Amsterdam, pp. 3-13

Lehnberg, W., Theede, H. (1979). Kombinierte Wirkungen von Temperatur, Salzgehalt und Cadmium auf Entwicklung, Wachstum und Mortalität der Larven von Mytilus edulis aus der westlıchen Ostsee. Helgoländer wiss. Meeresunters. 32: 179-199

Li, W. K. W. (1978). Kinetic analysis of interactive effects of cadmium and nitrate on growth of Thalassiosira fluviatilis (Bacillariophyceae). J. Phycol. 14: 454-460

Menzel, D. W., Case, J. (1977). Concept and design: Controlled ecosystem pollution experiment. Bull. mar. Sci. 27: 1-7

Mirkes, D. Z., Vernberg, W. B., DeCoursey, P. J. (1978). Effects of cadmium and mercury on the behavioral responses and development of Eurypanopeus depressus larvae. Mar. Biol. 47: 143-147

Nassogne, A. (1972). Etudes préliminaires sur le rôle du zooplankton dans la constitution et le transfer de la matière organique au sein de la chaîne alimentaire marine en mer Ligure. Thesis, Amsterdam

Nimmo, D. R., Rigby, R. A., Bahner, L. H., Sheppard, J. M. (1978). The acute and chronic effects of cadmium on the estuarine mysid, Mysidopsis bahia. Bull. environm. Contam. Toxicol. 19: 80-85 
Nünberg, H. W., Valenta, P. (1979). Studies on the ecotoxicological base lines and speciation of heavy metals in natural waters and rain. Proc. Int. Conf. management and control of heavy metals in the environment, London. CEP Consultants Ltd., Edinburgh, pp. 472-475

Pascoe, D., Mattey, D. L. (1977). Studies on the toxicity of cadmium to the threespined stickleback Gasterosteus aculeatus L. J. Fish Biol. 11: 207-215

Patin, S. A., Tkachenko, V. N., Ibragim, A. M., Fedotova, L. V. (1974). Effect of some metals on primary production in the coastal zone of the Caspian Sea. Oceanology (Moscow) 14: $72-74$

Pavicic, J., Järvanpää, T. (1974). Cadmium toxicity in adults and early larval stages of the mussel Mytilus galloprovincialis Lam. In: Comparative studies of food and environmental contamination. International Atomic Energy Agency, Vienna, Austria, pp. 179-188

Podamo, J. (1974). Essai de bilan annual du transfer de l'azote dans le bassin de chasse d'Ostende. I. Utilisation de l'azote par le phytoplankton et le phytobenthos. Hydrobiol. Bull. 8: 46-52

Premazzi, G., Bertone, A. F., Freddy, A., Ravera, O. (1978). Combined effects of heavy metals and chelating substances on Selenastrum cultures. Proc. Research seminar EEG and UBA, Berlin. UBA-Berichte 10/78: 169-187

Preston, A. (1973). Cadmium in the marine environment of the United Kingdom. Mar. Poll. Bull. 4: 105-107

Preston, A., Jefferies, D. F., Dutton, J. W. R., Harvey, B. R., Steele, A. K. (1972). British Isles coastal waters: The concentrations of selected heavy metals in sea water, suspended matter and biological indicators, a pilot survey. Environ. Pollut. 3: 69-82

Pugh, P. R. (1973). An evaluation of liquid scintillation counting technique for use in aquatic primary production studies. Limnol. Oceanogr. 18: 310-319

Raspor, B., Valenta, P., Nünberg, H. W., Branica, M. (1977). The chelation of cadmium with NTA in sea water as a model for the typical behaviour of trace metal chelates in natural waters. The science of the total environment 9: $87-109$

Ringelberg, J. (1973). Parameter dependent (temperature) tolerance levels and the influence of the complexity of the biological system. Hydrobiol. Bull. (Amsterdam) 7: 106-114

Robertson, A. (1968). The continuous plankton recorder: A method for studying the biomass of calanoid copepods. Bull, mar. Ecol. 6: 185-223

Rosenberg, R., Costlow, J. D., (1976). Synergistic effects of cadmium and salinity development of two estuarine crab species. Mar. Biol. 38: 291-303

Sheldon, R. W., Parsons, T R. (1967). A practical manual on the use of the Coulter Counter in marine science. Coulter Electronics Sales, Toronto

Sick, L. V., Baptist, G. J. (1979): Cadmium incorporation by the marine copepod Pseudodiaptomus coronatus. Limnol. Oceanogr. 24: 543-562

Sonntag, N. C., Parsons, T R. (1979). Mixing an enclosed, $1300 \mathrm{~m}^{3}$ water column. Effects on the planktonic food web. J. Plankton Res. 1: 85-102
Steemann-Nielsen, E. (1952). The use of radioactive carbon $\left(\mathrm{C}^{14}\right)$ for measuring organic production in the sea. $\mathrm{J}$. Cons. perm. int. Explor. Mer 18: 117-140

Strickland, J. D. H., Parsons, T. R. (1968). A practical handbook of sea water analysis. Bull. Fish. Res. Bd Can. 167: $1-311$

Strickland, J. D. H., Terhune, L. D. B. (1961). The study of in situ marine photosynthesis using a large plastic bag. Limnol. Oceanogr 6: 93-96

Sunda, W G., Engel, D. W., Thuotte, R. M. (1978). Effect of chemical speciation on toxicity of cadmium to grass shrimp, Palaemonetes pugio: Importance of free cadmium ion. Environm. Sci. Technol. 12: 409-413

Takahashi, M., Thomas, W H., Seibert, D. L. R., Beers, J., Koeller, P., Parsons, T. R. (1975). The replication of biological events in enclosed water columns. Arch. Hydrobiol. 76: $5-23$

Taylor, D. (1977). A summary of the data on the toxicity of various materials to aquatic life, Vol. II, cadmium. ICI Ltd. Report no. BL/A/1778: 1-22

Theede, H., Scholz, N., Fischer, H. (1979). Temperature and salinity effects on the acute toxicity of cadmium to Laomedea loveni (Hydrozoa). Mar. Ecol. Prog. Ser 1: $13-19$

Thurberg, F. P., Calabrese, A., Gould, E., Greig, R. A., Dawson, M. A., Tucker, R. K. (1977). Response of the lobster, Homarus americanus, to sublethal levels of cadmium and mercury. In: Vernberg, F. J., Calabrese, A., Thurnberg, F. P., Vernberg, W. B. (eds.) Physiological responses of marine biota to pollutants. Academic Press, New York, pp. 185-197

Tjioe, P. S., de Goeij, J. J. M., Houtman, J. P. W (1973). Automated chemical separations in routine activation analysis. J. radioanalyt. Chem. 16: 153-164

Tkachenko, V. N., Mortina, S. V., Lukankina, E. V. The method of toxicological experiments and some results of toxicological effects of heavy metals on marine and fresh water monocell algae. Trudy vses. nauchno-issled. Inst. morsk. ryb. Khoz. Okeanogr. 100: 63-67 (1974) (cited by Leland et al. 1977, Davies 1978)

Utermöhl, H. (1958). Zur Vervollkommnung der quantitativen Phytoplankton-Methodik. Mitt. int. Verein theor angew. Limnol. 9: 1-38

Vernberg, W. B., DeCoursey, P. J., O'Hara, J. (1974). Multiple environmental factor effects on physiology and behaviour of the fiddler crab, Uca pugilator. In: Vernberg, F. J., Vernberg, W. B. (eds.) Pollution and physiology of marine organisms. Academic Press, New York, San Francisco, London, pp. 381-425

Vollenweider, R. A. (1969). A manual on methods for measuring primary production in aquatic environments, Blackwell, Oxford

Westernhagen, H. von, Dethlefsen, V., Rosenthal, H., Fürstenberg, G., Klinckman, J. (1978). Fate and effects of cadrfium in an experimental marine ecosystem. Helgoländer wiss. Meeresunters. 31: 471-484

Wong, M. H., Ho, K. C., Kwok, T T. (1980). Degree of pollution of several major streams entering Tolo harbour HongKong. Mar. Poll. Bull. 11: 36-40 